Article

\title{
Human vs. Machine, the Eyes Have It. Assessment of Stemphylium Leaf Blight on Onion Using Aerial Photographs from an NIR Camera
}

\author{
Mary Ruth McDonald ${ }^{1, * \mathbb{D}}$, Cyril Selasi Tayviah ${ }^{1}$ and Bruce D. Gossen ${ }^{2}$ \\ 1 Department of Plant Agriculture, University of Guelph, Guelph, ON N1G 2W1, Canada; \\ stayviah@sun-brite.com \\ 2 Agriculture and Agri-Food Canada, Saskatoon, SK S7N 0X2, Canada; bruce.gossen@agr.gc.ca \\ * Correspondence: mrmcdona@uoguelph.ca
}

check for updates

Citation: McDonald, M.R.; Tayviah, C.S.; Gossen, B.D. Human vs.

Machine, the Eyes Have It. Assessment of Stemphylium Leaf Blight on Onion Using Aerial Photographs from an NIR Camera. Remote Sens. 2022, 14, 293. https:// doi.org/10.3390/rs14020293

Academic Editors: Nahina Islam, Santoso Wibowo and Johnson Ihyeh Agbinya

Received: 23 November 2021

Accepted: 6 January 2022

Published: 9 January 2022

Publisher's Note: MDPI stays neutral with regard to jurisdictional claims in published maps and institutional affiliations.

Copyright: (c) 2022 by the authors. Licensee MDPI, Basel, Switzerland. This article is an open access article distributed under the terms and conditions of the Creative Commons Attribution (CC BY) license (https:/ / creativecommons.org/licenses/by/ $4.0 /)$.

\begin{abstract}
Aerial surveillance could be a useful tool for early detection and quantification of plant diseases, however, there are often confounding effects of other types of plant stress. Stemphylium leaf blight (SLB), caused by the fungus Stemphylium vesicarium, is a damaging foliar disease of onion. Studies were conducted to determine if near-infrared photographic images could be used to accurately assess SLB severity in onion research trials in the Holland Marsh in Ontario, Canada. The site was selected for its uniform soil and level topography. Aerial photographs were taken in 2015 and 2016 using an Xnite-Canon SX230NDVI with a near-infrared filter, mounted on a modified Cine Star8 MK Heavy Lift RTF octocopter UAV. Images were taken at $15-20 \mathrm{~m}$ above the ground, providing an average of $0.5 \mathrm{~cm} /$ pixel and a field of view of $15 \times 20 \mathrm{~m}$. Photography and ground assessments of disease were carried out on the same day. NDVI (normalized difference vegetation index), green NDVI, chlorophyll index and plant senescence reflective index (PSRI) were calculated from the images. There were differences in SLB incidence and severity in the field plots and differences in the vegetative indices among the treatments, but there were no correlations between disease assessments and any of the indices.
\end{abstract}

Keywords: Stemphylium; onion; remote sensing; NDVR; drones; NIR; image analysis

\section{Introduction}

Aerial photographs taken from a UAV platform are increasingly being used in routine agricultural assessments, such as weed identification and quantification, and crop staging [1]. Advances in the technology of both unmanned aerial vehicles (UAVs) and the sensors they carry have increased the potential for use of remote sensing in a wide range of areas $[2,3]$ including management of diseases in crops. Early detection and identification of diseases using aerial reconnaissance, especially in high-value crops, could facilitate disease management and reduce the risk of subsequent losses in crop yield and quality. To date, however, this technology has only rarely been used in assessments of plant diseases [4-9] and the results have often not lived up to expectations [10].

Onion (Allium cepa L.) is a high-value crop that is grown around the world. Much of the production in eastern North America occurs on soils that are extremely high in organic matter (45-80\% organic matter, known as muck soils). Many of these sites are drained marshes, where the deep, rich, uniform soils and availability of irrigation are highly suited to onion production, but also favor fungal diseases, such as Stemphylium leaf blight on onion [11].

The rich muck soil and flat, uniform topography of the Holland Marsh in Ontario, Canada, was selected as an almost ideal site for the assessment of aerial photography for disease detection and quantification. The soil is deep, consistent, and uniform in color, texture and drainage, irrigation is routinely applied as needed [11], and a single disease of 
onion, SLB, was predominate at the site [12]. As a result, other potentially confounding causes of plant stress were minimized, and disease assessment was relatively simple and consistent.

The predominant disease of onion at the Holland Marsh during the study period was Stemphylium leaf blight $[12,13]$ caused by Stemphylium vesicarium (Wallr.) E.G. Simmons (teleomorph: Pleospora herbarum [Pers.] Rabenh.). The initial visual symptoms are small, yellow to tan, water-soaked lesions, followed by extensive blighting of the leaf blade, starting at the tip [14]. This results in leaf necrosis, lodging [15,16], and reduced bulb size [15]. The biology, epidemiology and management of Stemphylium leaf blight have recently been reviewed [11].

No strong resistance to Stemphylium leaf blight is currently available in commercial onion cultivars $[12,17,18]$, so the application of foliar fungicides $[19,20]$ is often required to maintain yield and quality. On some hosts, $S$. vesicarium has been shown to produce host-specific toxins after infection that are associated with extensive tissue necrosis [21,22]. Early detection is important to minimize yield losses [23,24].

Remote sensing can be used to measure the amount of reflected radiation from a crop canopy $[25,26]$ to detect crop diseases with minimal disturbance to the crop $[3,27]$. Specialized cameras can capture images containing reflectance data in the visible (400-685 nm), red-edge (690-730 nm), near-infrared (NIR, 730-850 nm), and shortwave-infrared (SWIR, $850-2500 \mathrm{~nm})$ spectra $[2,5,28]$.

Vegetative indices that compare the relative reflectance in two or more spectral regions that are sensitive to disease presence can be calculated from remote sensing images [29,30]. For example, the normalized difference vegetative index (NDVI) has been used to detect citrus trees infected with Huanglongbing disease [5] and oil palm trees infected with ganoderma stem base rot [4]. However, the major limitation of vegetative indices for disease detection is that changes in chlorophyll content are indicative of many kinds of stress, such as water deficiency, nitrogen deficiency and heat stress, not just plant disease [31]. The trial sites in the current study were chosen and managed to provide consistent plant growth and avoid moisture and nutrient stresses.

The overall goal of this study was to investigate the potential of using UAVs mounted with a simple and relatively inexpensive camera (fitted with red, green and infrared filters) as an efficient method to assess plant disease in research plots, with the long term goal of assessing onion fields as part of an integrated pest management program for onion. The relationship between four selected vegetative indices and Stemphylium leaf blight levels was investigated.

\section{Materials and Methods}

\subsection{Onion Plots and Regions of Interest}

Two onion trials (Figure 1) at a site near the University of Guelph Muck Crops Research Station in Holland Marsh, Ontario, Canada, were selected as the two regions of interest (ROI) for the study in 2015. The results from the visual assessments of disease in these trials have already been published: the cultivar trial in 2019 [12] and the fungicide timing trial in 2021 [20]. The details are briefly summarized here. There were twelve cultivars that did not receive any fungicide spraysand the arrangement of the experiments is shown in Figure 1. All treatments (except the non-sprayed check) in the fungicide timing trials were sprayed with the combination of fluopyram and pyrimethanil fungicide, sold commercially as Luna Tranquility (Bayer Crop Science). The trials were arranged in a randomized complete block design with four replicates. Each bed of onions was $1.6 \times 5 \mathrm{~m}$, with four rows per plot, $2 \mathrm{~m}$ between blocks and $40 \mathrm{~cm}$ between rows. Onion plugs ( $2-3$ seedlings per plug) were transplanted on 25 May 2015 with $10 \mathrm{~cm}$ between plugs. There was one bed per replicate plot in the cultivar trial and two beds per replicate plot in the fungicide trials. 

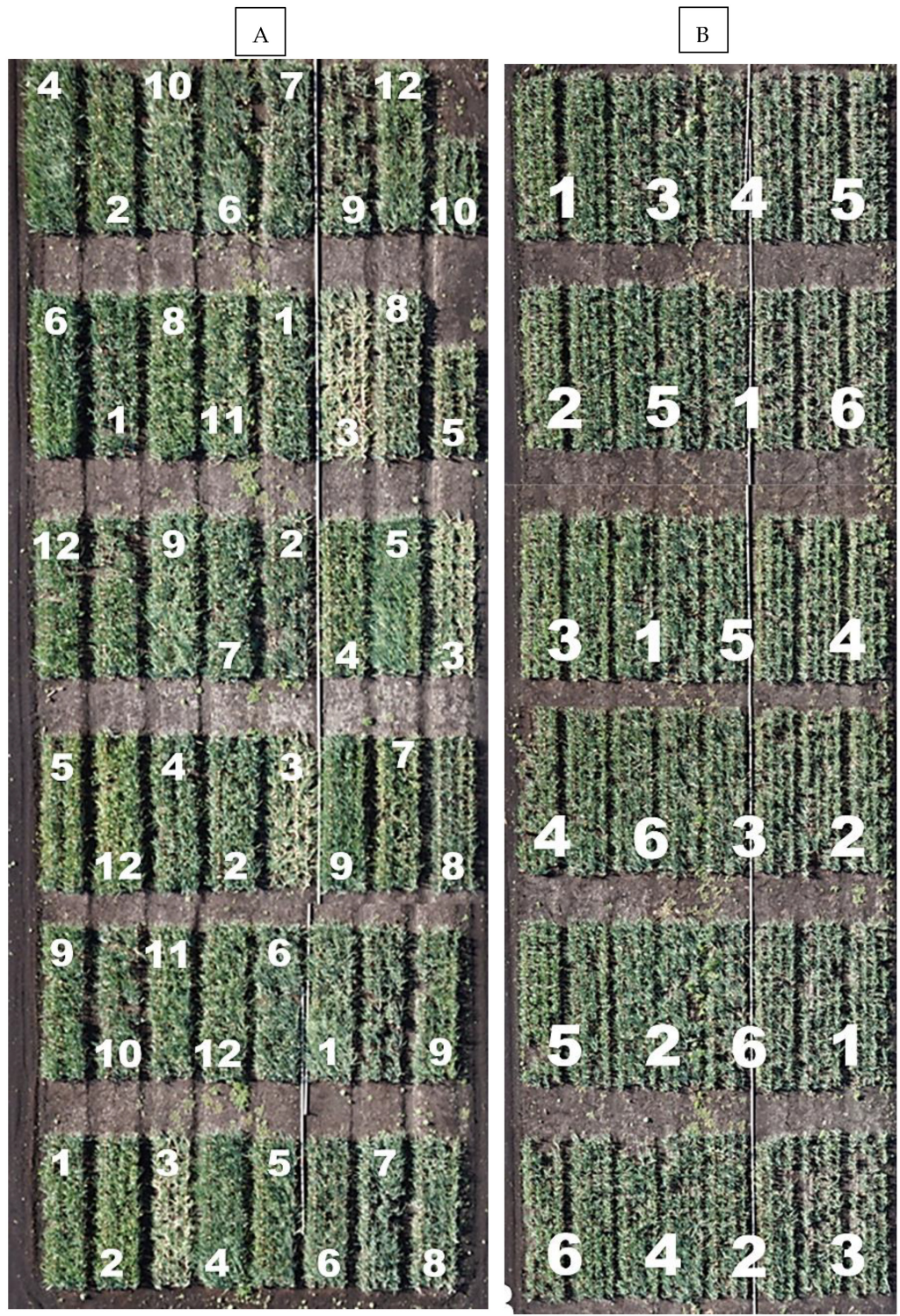

Figure 1. Plot area and treatment numbers (in white) for onion trials at the Holland Marsh, ON in 2015: (A) Cultivar trial (each number represents a different cultivar, three replicate blocks shown) and (B) Fungicide application-timing trial (each number represents a different treatment, four replicate blocks shown, individual blocks arranged from top to bottom).

In 2016, only the fungicide timing trial was assessed because of poor emergence in some lines of the cultivar trial. The seed of some cultivars was old and fresh seed was not available. The crop was direct seeded at 35 seeds $\mathrm{m}^{-1}$ on 4 May 2016, with four double rows per bed and two beds per replicate plot.

The acquisition of aerial images (visible and near-infrared) was conducted by High Eye Imaging Inc. (Wasaga, ON, Canada). The camera was a Xnite-Canon SX230NDVI (Canon USA Inc., Melville, NY, USA) mounted on a modified Cine Star-8 MK Heavy Lift RTF octocopter UAV (The Quadrocopter Company, Columbia Falls, MT, USA) (Figure 2). Ground reflectance measurements were not taken in the study. 


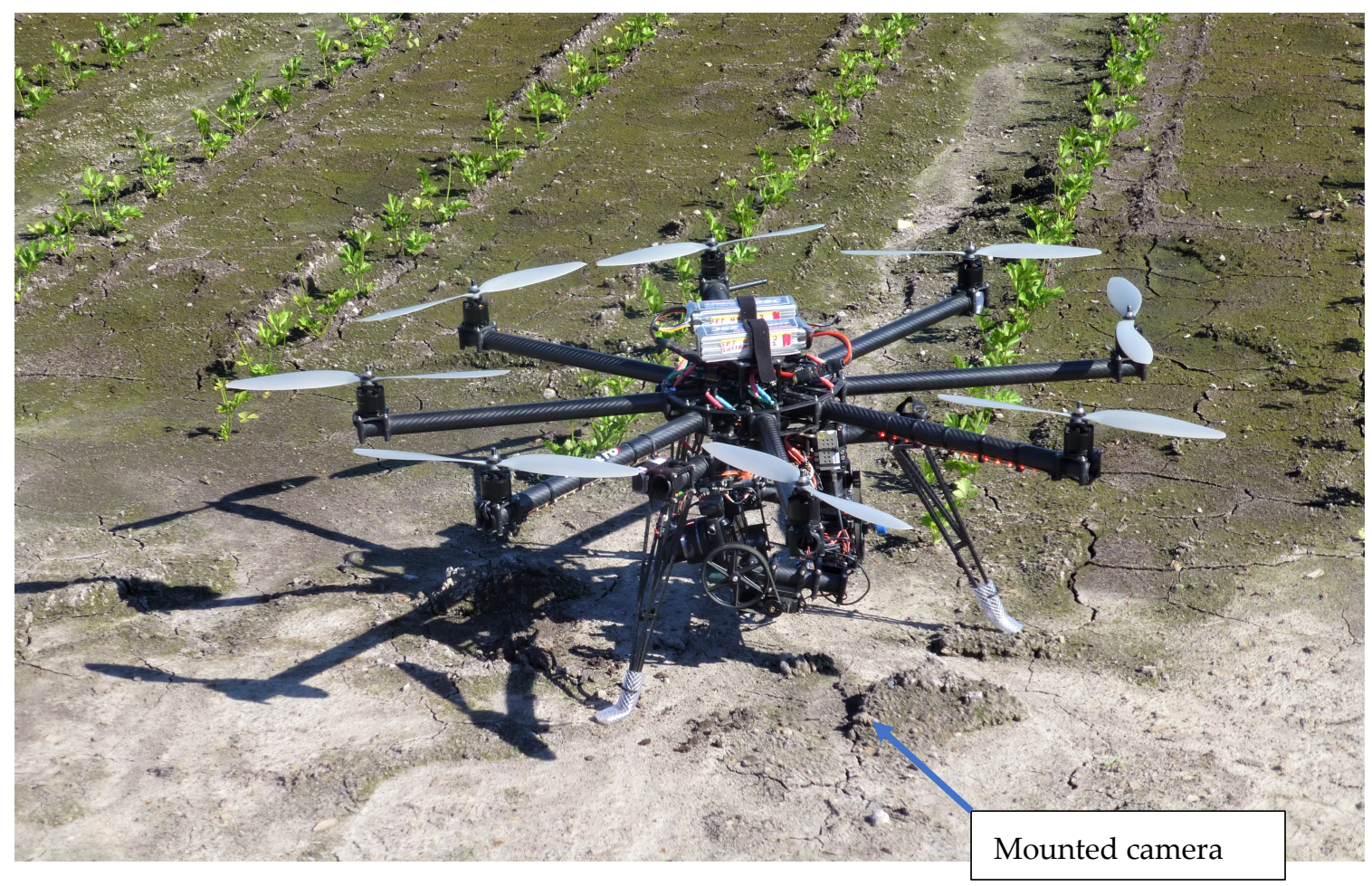

Figure 2. A modified Cine Star-8 MK Heavy Lift RTF octocopter mounted with a camera for aerial image collection at the Holland Marsh, Ontario in July 2015.

Aerial images were taken in the ROIs on 29 June, 13 July, 27 July and 4 August in 2015 and 27 June, 11 July, 25 July and 2 August in 2016. In 2015, images were captured with the camera with the red-region filter replaced with a near-infrared filter, and the images were saved in JPEG (joint photographic experts group) format. The images were taken from 15-20 $\mathrm{m}$ and 25-30 $\mathrm{m}$ above the ground. In 2016, the images were taken from 15-20 $\mathrm{m}$ above ground with the camera in which the blue-region filter was replaced with a near infrared filter (Figure 3), and the images were saved in TIFF format (tagged image file format).

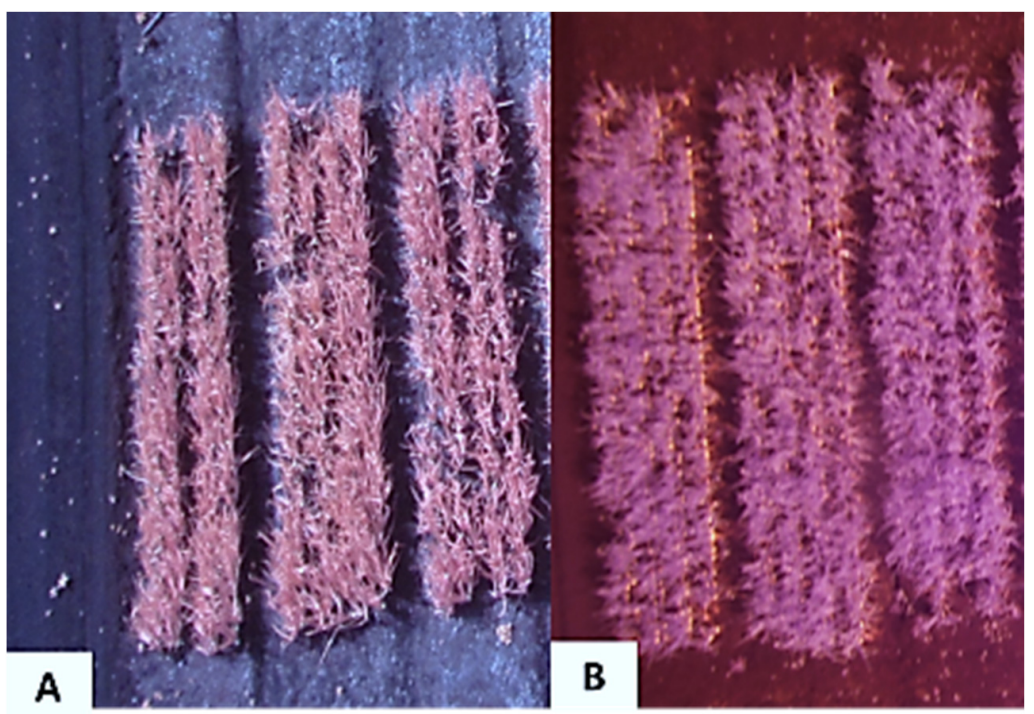

Figure 3. Aerial infrared image of onion trials taken on 4 August 2016 with a Xnite-Canon SX230NDVI camera with (A) the red-filter or (B) blue-filter replaced with a near-infrared filter at the Muck Crops Research Station, Holland Marsh, Ontario. 
Visual assessments of SLB incidence and leaf dieback in each replicate of each trial (ground truthing) were collected. The ratings were taken every second week on the same day as the aerial images. In 2015, the number of lesions was assessed on one transplant plug (consisting of 2-3 seedlings) at each of eight places along the middle two rows of each $1.6 \times 5 \mathrm{~m}$ bed, for a total of 16-24 plants per plot. Plugs were assessed at roughly 1-m intervals along each row, starting $1 \mathrm{~m}$ from the end of the row. The first and second fully developed outer leaves (counting from the youngest leaf) on the two largest seedlings per plug were assessed (32 leaves) for lesions. The incidence (\%) of Stemphylium leaf blight per replicate plot was calculated by dividing the number of transplant plugs with disease symptoms by the total number of plugs assessed, then multiplying by 100. Each replicate plot consisted of one bed for the cultivar trial and two side-by-side beds for the fungicide timing trial. The mean number of lesions per leaf was also calculated. In 2016, the incidence was assessed on 100 plants in the middle two rows of each plot, and lesions per leaf were counted on 10 consecutive plants in each of the two middle rows (total $=40$ leaves). Leaf dieback, chlorotic, or necrotic leaf tissue, was assessed on the fifth and sixth fully developed true leaves of each plant, counted from the youngest leaf. The length of dieback symptom relative to the total leaf length for each leaf was measured with a $60-\mathrm{cm}$ clear plastic ruler. The mean leaf dieback (\%) for each plot was calculated. The plants selected for leaf dieback assessments were not the same plants used for lesion counts.

The first lesions of Stemphylium leaf blight lesions in 2015 were observed on 29 June. Leaf dieback (severity) was observed 21 days after observing the initial lesions. The leaf dieback in each plot was assessed on 20 July, 27 July, 4 August and 14 August. 2015. The initial lesions per leaf in 2016 were assessed on 7 July 2016, leaf dieback was observed 12 days later and leaf dieback was assessed on 19 July, 25 July, 3 August and 11 August.

\subsection{Image Analysis and Vegetative Indices}

The images from the ROI were analyzed using Whitebox Geospatial Analysis Tools (University of Guelph, Guelph, ON, Canada). Only the images acquired from 15-20 m above ground level were processed. These images covered an area of $15 \times 30 \mathrm{~m}$ per ROI, with 24 beds each as shown in Figure 1. The spatial resolution of the images was calculated using a field of view (FOV) chart for the camera used. The image resolution yielded a pixel size of about $3.1 \mathrm{~cm}$ per pixel. Scripts were written using Python language (Python Software Foundation) were used to calculate four selected vegetative indices (Table 1) from the images.

Table 1. Descriptions of the four vegetative indices calculated from aerial images of onion field trials at the Muck Crops Research Station, Holland Marsh, ON in 2015 and 2016.

\begin{tabular}{|c|c|c|c|}
\hline Index & Wavebands & Crop Parameter & Reference \\
\hline \multicolumn{4}{|c|}{ Normalized vegetative indices (NDVI) } \\
\hline NDVI & $\mathrm{NDVI}=\frac{R_{N I R}-R_{R E D}}{R_{N I R}+R_{R E D}}$ & $\begin{array}{l}\text { Photosynthetically active } \\
\text { radiation (PAR) } \\
\text { intercepted/biomass }\end{array}$ & {$[32,33]$} \\
\hline $\begin{array}{l}\text { Green NDVI } \\
(\text { GNDVI })\end{array}$ & GNDVI $=\frac{R_{N I R}-R_{G R E E N}}{R_{N I R}+R_{G R E E N}}$ & PAR/biomass & {$[33,34]$} \\
\hline \multicolumn{4}{|c|}{ Chlorophyll index $(\mathrm{CI})$} \\
\hline $\mathrm{CI}$ & $\begin{array}{r}\mathrm{CI}=\left(R_{N I R} / R_{\text {GREEN }}\right)-1 \\
\text { Plant senescence re }\end{array}$ & $\begin{array}{l}\text { Chlorophyll } \\
\text { tive index (PSRI) }\end{array}$ & [34] \\
\hline PSRI & PSRI $=\frac{\left(R_{R E D}-R_{G R E E N}\right)}{R_{N I R}}$ & Plant senescence & [35] \\
\hline
\end{tabular}

NDVI, GNDVI and CI relate to photosynthetic activity and plant productivity, PSRI assesses the ratio of carotenoids and chlorophyll and is a quantitative measure of leaf senescence.

The vegetative indices for each bed were calculated for $0.4 \times 3 \mathrm{~m}(129 \times 968$ pixels $)$ portions from the center of each bed to avoid any edge effects. This is $15 \%$ of the area of each bed. 
In 2015, images taken on 29 June could not be effectively assessed because the small seedlings could not be separated from the background of black muck soil. Additionally, the images taken on 27 July could not be assessed effectively because they were taken at an angle instead of vertically. There was no red band in the images taken in 2015, so the program replaced the red values with reflectance from the blue region. Similarly, images taken on 27 June and 11 July 2016 could not be assessed because plants could not be separated from the background.

\subsection{Statistical Analysis}

PROC GLM in SAS (ver. 9.4, SAS Institute Inc., Cary, NC, USA) was used for the analysis of variance of the visual assessments of Stemphylium leaf blight incidence and the calculated vegetative indices. Means were separated using Tukey's multiple range test $(p \leq 0.05)$. No outliers were identified using Lund's test. The data for the vegetative indices were not normally distributed when assessed using PROC UNIVARIANT. Data were not pooled across years as the analysis showed a repetition (year) $\times$ treatment interaction. The relationship between Stemphylium leaf blight incidence and severity was assessed with Pearson correlation. The relationships between incidence and severity and the vegetative indices were assessed using Spearman's rank correlation (nonparametric) at $p<0.05$ in PROC CORR.

\section{Results}

\subsection{Image Analysis}

The NIR images acquired at 15-20 $\mathrm{m}$ (Figure 3A) had an average ground sampling distance (GSD) of $0.5 \mathrm{~cm} /$ pixel and an average FOV of $15 \times 20 \mathrm{~m}$. These images had higher resolution compared to images taken from $25-30 \mathrm{~m}$ (Figure 3B). The images were taken from $25-30 \mathrm{~m}$ above ground had an average GSD of $0.75 \mathrm{~cm}$ per pixel with a wider average FOV of $24 \times 31 \mathrm{~m}$.

\subsection{Disease and Vegetative Indices}

The assessments of Stemphylium leaf blight incidence and leaf dieback in the cultivar and fungicide timing trials have been published previously [12,20]. Briefly, Stemphylium leaf blight incidence and leaf dieback were higher in 2015 than in 2016. Lesions were first detected on 29 June 2015 and 11 July 2016. Stemphylium leaf blight incidence and leaf dieback were higher in August relative to July in both years.

There were significant differences in incidence and percentage of leaf dieback among cultivars and fungicide timing treatments each year (Tables 2-4). For example, in the cultivar trial in 2015, cv. Pontiac had the lowest leaf blight incidence on 13 July, Milestone had the highest incidence, and all of the other lines were intermediate. On 4 August, the pattern was similar, with Pontiac lowest, Milestone (plus Trailblazer) highest, and the others intermediate. Leaf dieback on 4 August showed a similar pattern, except that dieback in cv. Highlander was highest, despite being at the low end for incidence (Table 2). In the fungicide timing trial, Stemphylium leaf blight incidence and leaf dieback were highest in the unsprayed control at both dates in 2015 (Table 3). In 2016, the incidence was highest in the unsprayed control but there were no differences in leaf dieback among the treatments (Table 4). 
Table 2. Stemphylium leaf blight incidence, severity (leaf dieback) in July and August and four vegetative indices were calculated for an onion cultivar trial at the Muck Crops Research Station, Holland Marsh, ON in 2015.

\begin{tabular}{|c|c|c|c|c|c|c|c|}
\hline \multirow{2}{*}{$\begin{array}{l}\text { Date and } \\
\text { Cultivar }\end{array}$} & \multirow{2}{*}{ Incidence } & \multirow{2}{*}{ Severity } & \multicolumn{4}{|c|}{ Vegetative Indices ${ }^{1}$} & \multirow[b]{2}{*}{ Maturity } \\
\hline & & & NDVI & GNDVI & CI & PSRI & \\
\hline \multicolumn{8}{|c|}{13 July (7-8 leaves) } \\
\hline Pontiac & $51 c^{2}$ & nd & $0.22 \mathrm{a}$ & $0.06 \mathrm{bcd}$ & $0.08 \mathrm{~cd}$ & $0.37 \mathrm{~cd}$ & 115 \\
\hline Highlander & $55 \mathrm{bc}$ & nd & $0.13 \mathrm{ab}$ & $0.04 \mathrm{~cd}$ & $0.05 \mathrm{~cd}$ & $0.37 \mathrm{~cd}$ & 90 \\
\hline LaSalle & $55 \mathrm{bc}$ & nd & $0.21 \mathrm{a}$ & $0.06 \mathrm{bcd}$ & $0.10 \mathrm{bcd}$ & $0.39 \mathrm{bcd}$ & 103 \\
\hline Prince & $55 \mathrm{bc}$ & nd & $0.09 \mathrm{~b}$ & $0.20 \mathrm{a}$ & $0.35 \mathrm{a}$ & $0.49 \mathrm{abc}$ & 105 \\
\hline Stanley & $55 \mathrm{bc}$ & nd & $0.09 \mathrm{~b}$ & $0.20 \mathrm{a}$ & $0.34 \mathrm{a}$ & $0.43 \mathrm{bcd}$ & 105 \\
\hline Hendrix & $58 \mathrm{bc}$ & nd & $0.16 \mathrm{ab}$ & $0.03 \mathrm{~cd}$ & $0.03 \mathrm{~cd}$ & $0.39 \mathrm{bcd}$ & 108 \\
\hline Patterson & $59 \mathrm{abc}$ & nd & $0.19 \mathrm{a}$ & $0.14 \mathrm{abc}$ & $0.23 \mathrm{abc}$ & $0.51 \mathrm{ab}$ & 104 \\
\hline Madras & $59 \mathrm{abc}$ & nd & $0.17 \mathrm{ab}$ & $0.17 \mathrm{ab}$ & $0.30 \mathrm{ab}$ & $0.59 \mathrm{a}$ & 102 \\
\hline Genesis & $61 \mathrm{abc}$ & nd & $0.21 \mathrm{a}$ & $0.02 \mathrm{~cd}$ & $0.01 \mathrm{~d}$ & $0.34 \mathrm{~d}$ & 108 \\
\hline Trailblazer & $63 \mathrm{ab}$ & nd & $0.17 \mathrm{ab}$ & $0.10 \mathrm{a}-\mathrm{d}$ & $0.16 \mathrm{a}-\mathrm{d}$ & $0.47 \mathrm{a}-\mathrm{d}$ & 95 \\
\hline Hamlet & $66 \mathrm{ab}$ & nd & $0.18 \mathrm{ab}$ & $0.01 \mathrm{~d}$ & $0.03 \mathrm{~cd}$ & $0.45 \mathrm{bcd}$ & 108 \\
\hline Milestone & $70 \mathrm{a}$ & nd & $0.20 \mathrm{a}$ & $0.09 \mathrm{a}-\mathrm{d}$ & $0.13 \mathrm{a}-\mathrm{d}$ & $0.39 \mathrm{bcd}$ & 110 \\
\hline \multicolumn{8}{|c|}{4 August (11-12 leaves, bulbing) } \\
\hline Pontiac & $68 \mathrm{~b}$ & $35 \mathrm{~b}$ & $0.21 \mathrm{ab}$ & $0.02 \mathrm{c}$ & $0.04 \mathrm{c}$ & $0.46 \mathrm{~cd}$ & 115 \\
\hline Highlander & $79 \mathrm{ab}$ & $62 \mathrm{a}$ & $0.23 \mathrm{a}$ & $0.04 \mathrm{c}$ & $0.09 \mathrm{bc}$ & $0.47 \mathrm{bcd}$ & 90 \\
\hline LaSalle & $89 a$ & $41 \mathrm{~b}$ & $0.13 \mathrm{a}-\mathrm{d}$ & $0.08 \mathrm{bc}$ & $0.13 b c$ & $0.45 \mathrm{~cd}$ & 103 \\
\hline Prince & $78 \mathrm{ab}$ & $43 \mathrm{~b}$ & $0.08 \mathrm{~cd}$ & $0.16 \mathrm{ab}$ & $0.28 \mathrm{ab}$ & $0.62 \mathrm{a}$ & 105 \\
\hline Stanley & $81 \mathrm{ab}$ & $38 \mathrm{~b}$ & $0.12 \mathrm{bcd}$ & $0.11 b c$ & $0.18 \mathrm{bc}$ & $0.62 \mathrm{a}$ & 105 \\
\hline Hendrix & $80 \mathrm{ab}$ & $37 \mathrm{~b}$ & $0.21 \mathrm{ab}$ & $0.01 \mathrm{c}$ & $0.02 \mathrm{c}$ & $0.44 \mathrm{~cd}$ & 108 \\
\hline Patterson & $82 \mathrm{ab}$ & $42 \mathrm{~b}$ & $0.13 \mathrm{a}-\mathrm{d}$ & $0.13 \mathrm{abc}$ & $0.21 \mathrm{abc}$ & $0.56 \mathrm{abc}$ & 104 \\
\hline Madras & $85 \mathrm{ab}$ & $46 \mathrm{~b}$ & $0.02 \mathrm{~d}$ & $0.25 \mathrm{a}$ & $0.42 \mathrm{a}$ & $0.60 \mathrm{ab}$ & 102 \\
\hline Genesis & $85 \mathrm{ab}$ & $42 \mathrm{~b}$ & $0.23 \mathrm{ab}$ & $0.04 \mathrm{bc}$ & $0.09 \mathrm{bc}$ & $0.44 \mathrm{~cd}$ & 108 \\
\hline Trailblazer & $87 \mathrm{a}$ & $42 \mathrm{~b}$ & $0.16 \mathrm{abc}$ & $0.09 \mathrm{bc}$ & $0.14 b c$ & $0.53 \mathrm{a}-\mathrm{d}$ & 95 \\
\hline Hamlet & $83 \mathrm{ab}$ & $46 \mathrm{~b}$ & $0.17 \mathrm{abc}$ & $0.07 \mathrm{bc}$ & 0.11 bc & $0.40 \mathrm{~d}$ & 108 \\
\hline Milestone & $90 \mathrm{a}$ & $43 \mathrm{~b}$ & $0.19 \mathrm{abc}$ & $0.03 \mathrm{c}$ & $0.03 c$ & $0.50 \mathrm{a}-\mathrm{d}$ & 110 \\
\hline
\end{tabular}

${ }^{1}$ Vegetative indices: NDVI = normalized difference vegetative index, GNDVI = green NDVI (GNDVI), CI = chlorophyll index and PSRI = plant senescence reflectance index. Maturity-days to harvest maturity. ${ }^{2}$ Means in a column followed by the same letter do not differ based on Tukey's multiple range test at $p>0.05$, ns $=$ not significant, nd $=$ no data.

Table 3. Stemphylium leaf blight incidence, leaf dieback, and vegetative indices measured on onions in a fungicide application timing trial at the Muck Crops Research Station, Holland Marsh in 2015.

\begin{tabular}{|c|c|c|c|c|c|c|}
\hline \multirow{2}{*}{ Fungicide Treatment } & \multirow{2}{*}{ Incidence } & \multirow{2}{*}{ Leaf Dieback } & \multicolumn{4}{|c|}{ Vegetative Indices ${ }^{1}$} \\
\hline & & & NDVI & GNDVI & CI & PSRI \\
\hline \multicolumn{7}{|c|}{13 July (7-8 leaves) } \\
\hline CP1 & $59 c^{2}$ & nd & $0.08 \mathrm{~ns}$ & $0.16 \mathrm{ab}$ & $0.03 \mathrm{c}$ & $0.30 \mathrm{~b}$ \\
\hline TOMCAST 15 & $65 \mathrm{bc}$ & nd & 0.10 & $0.07 \mathrm{~b}$ & $0.15 \mathrm{ab}$ & $0.31 \mathrm{~b}$ \\
\hline BOTCAST & $73 \mathrm{ab}$ & nd & 0.09 & $0.07 \mathrm{~b}$ & $0.15 \mathrm{a}$ & $0.34 \mathrm{~b}$ \\
\hline STEMCAST & $74 \mathrm{ab}$ & nd & 0.09 & $0.13 \mathrm{ab}$ & $0.08 \mathrm{bc}$ & $0.29 \mathrm{~b}$ \\
\hline LDR & $79 a$ & nd & 0.08 & $0.21 \mathrm{a}$ & $0.04 \mathrm{c}$ & $0.39 \mathrm{ab}$ \\
\hline Unsprayed & $85 a$ & nd & 0.09 & $0.13 \mathrm{ab}$ & $0.12 \mathrm{ab}$ & $0.47 \mathrm{a}$ \\
\hline \multicolumn{7}{|c|}{4 August (11-13 leaves, bulbing) } \\
\hline CP1 & $74 \mathrm{c}$ & $29 \mathrm{~b}$ & $0.09 \mathrm{ab}$ & $0.06 \mathrm{~ns}$ & $0.05 \mathrm{c}$ & $0.57 \mathrm{ab}$ \\
\hline TOMCAST & 79 bc & $29 \mathrm{~b}$ & $0.09 \mathrm{ab}$ & 0.05 & $0.08 \mathrm{bc}$ & $0.58 \mathrm{ab}$ \\
\hline BOTCAST & $85 \mathrm{~b}$ & $30 \mathrm{~b}$ & $0.06 \mathrm{~b}$ & 0.04 & $0.12 \mathrm{ab}$ & $0.46 \mathrm{a}$ \\
\hline STEMCAST & $86 b$ & $36 \mathrm{~b}$ & $0.10 \mathrm{a}$ & 0.05 & $0.05 \mathrm{c}$ & $0.63 b$ \\
\hline LDR & $90 \mathrm{ab}$ & $32 b$ & $0.07 \mathrm{ab}$ & 0.05 & $0.12 \mathrm{ab}$ & $0.50 \mathrm{ab}$ \\
\hline Unsprayed & $98 \mathrm{a}$ & $49 a$ & $0.06 \mathrm{~b}$ & 0.04 & $0.16 \mathrm{a}$ & $0.51 \mathrm{ab}$ \\
\hline
\end{tabular}

${ }^{1}$ Vegetative indices calculated: NDVI = normalized difference vegetative index, GNDVI = green NDVI (GNDVI), $\mathrm{CI}=$ chlorophyll index and PSRI = plant senescence reflectance index. For details of treatments, see Stricker et al 2021 [20]. ${ }^{2}$ Means in a column followed by the same letter did not differ based on Tukey's multiple range test at $p>0.05, \mathrm{~ns}=$ not significant, $\mathrm{nd}=$ no data. 
Table 4. Stemphylium leaf blight incidence, leaf dieback, and vegetative indices were measured on onions in a fungicide application timing trial at the MCRS, Holland Marsh in 2016.

\begin{tabular}{|c|c|c|c|c|c|c|}
\hline \multirow{2}{*}{$\begin{array}{l}\text { Fungicide } \\
\text { Treatment }\end{array}$} & \multirow{2}{*}{$\begin{array}{c}\text { Incidence } \\
(\%)\end{array}$} & \multirow{2}{*}{ Leaf Dieback } & \multicolumn{4}{|c|}{ Vegetative Indices ${ }^{1}$} \\
\hline & & & NDVI & GNDVI & CI & PSRI \\
\hline \multicolumn{7}{|c|}{25 July (7-8 leaves) } \\
\hline TOMCAST 15 & $7 b^{2}$ & $4 \mathrm{~ns}$ & $0.18 \mathrm{ab}$ & $0.27 \mathrm{~ns}$ & $0.33 \mathrm{a}$ & $0.19 \mathrm{ab}$ \\
\hline TOMCAST 15/25 & $11 \mathrm{~b}$ & 7 & $0.17 b$ & 0.22 & $0.19 \mathrm{~b}$ & $0.21 \mathrm{a}$ \\
\hline $\mathrm{CP} 2$ & $11 \mathrm{~b}$ & 1 & $0.18 \mathrm{ab}$ & 0.24 & $0.09 \mathrm{~b}$ & $0.17 \mathrm{ab}$ \\
\hline BOTCAST & $12 \mathrm{~b}$ & 6 & $0.20 \mathrm{ab}$ & 0.35 & $0.34 \mathrm{a}$ & $0.15 \mathrm{~b}$ \\
\hline TOMCAST 15R & $15 \mathrm{ab}$ & 5 & $0.16 \mathrm{~b}$ & 0.21 & $0.08 \mathrm{~b}$ & $0.19 \mathrm{ab}$ \\
\hline Control & $25 \mathrm{a}$ & 10 & $0.28 \mathrm{a}$ & 0.41 & $0.20 \mathrm{ab}$ & $0.17 \mathrm{ab}$ \\
\hline \multicolumn{7}{|c|}{2 August (10-12 leaves, bulbing) } \\
\hline TOMCAST 15 & $8 \mathrm{~b}$ & $8 \mathrm{~ns}$ & $0.21 \mathrm{ab}$ & $0.10 \mathrm{~ns}$ & $0.03 \mathrm{bc}$ & $0.62 \mathrm{~ns}$ \\
\hline TOMCAST 1525 & $12 \mathrm{~b}$ & 8 & $0.23 \mathrm{a}$ & 0.10 & $0.02 \mathrm{c}$ & 0.64 \\
\hline $\mathrm{CP} 2$ & $12 \mathrm{~b}$ & 10 & $0.15 \mathrm{bc}$ & 0.12 & $0.04 \mathrm{ab}$ & 0.76 \\
\hline BOTCAST & $13 \mathrm{~b}$ & 9 & $0.15 \mathrm{bc}$ & 0.11 & $0.04 \mathrm{ab}$ & 0.66 \\
\hline TOMCAST 15R & $17 \mathrm{ab}$ & 12 & $0.22 \mathrm{ab}$ & 0.13 & $0.02 c$ & 0.77 \\
\hline Control & $27 \mathrm{a}$ & 17 & $0.11 \mathrm{c}$ & 0.09 & $0.05 \mathrm{a}$ & 0.74 \\
\hline
\end{tabular}

${ }^{1}$ Vegetative indices calculated: NDVI = normalized difference vegetative index, GNDVI = green NDVI (GNDVI) $\mathrm{CI}=$ chlorophyll index and PSRI = plant senescence reflectance index. For details of treatments, see Stricker et al., 2021 [20]. ${ }^{2}$ Means in a column followed by the same letter do not differ based on Tukey's multiple range test at $p>0.05, \mathrm{~ns}=$ not significant.

Images taken on the earliest dates could not be analyzed because of the high intensity of the black muck soil in the background. There were differences among treatments in the vegetative indices taken later in the season (Tables 2-4), but these differences were not correlated with differences in Stemphylium leaf blight incidence and severity in the three trials, except CI correlated with SLB incidence and severity in August in the fungicide trial in 2015 (Table 5).

In the cultivar trial in 2015, PSRI values were generally higher than the other vegetative indices. Additionally, PSRI values were higher in August relative to July, which corresponded with leaf blight incidence and leaf dieback (Table 2). However, there was no correlation between cultivar maturity (days to harvest maturity, as provided by the seed companies) and PSRI in July $(\mathrm{r}=-0.142, p=0.67)$ or August $(\mathrm{r}=-0.43, p=0.17$, Spearman's rank correlation). GNDVI values were generally lower than NDVI.

There were only a few relationships (Spearman's rank correlation) among the different indices in this study (Table 5) and no consistent pattern was found. In the cultivar trial, there was a relationship between CI and GNDVI in July and August and GNDVI was correlated with PSRI in July. In the fungicide timing trial in 2015, NDVI and PSRI were correlated in July and August and CI was correlated to NDVI in July. GNDVI was related to $\mathrm{CI}$, but it was a negative association. There were five significant correlations among the indices in the 2016 fungicide trial, but the pattern was different from the other trials. NDVI was correlated with GNDVI in July and August and there was a negative relationship between NDVI and CI in August. GNDVI was correlated with PSRI in July. This was the only case where the same relationship was found in two trials. CI was related to PSRI in the 2016 trial (Table 5).

In an ideal situation, the vegetative indices taken early in the season would provide an indication of stress caused by an early infection and be related to the level of disease severity that developed later. The relationship between the indices found in July was tested for correlation with disease severity in August. There were no significant relationships. Spearman's correlation coefficients ranged from -0.25 to 0.16 . 
Table 5. Correlation matrix for Stemphylium leaf blight (SLB) incidence and severity in July and August in relation to four vegetative indices from onion trials conducted at the Muck Crops Research Station, Ontario in 2015 and 2016.

\begin{tabular}{|c|c|c|c|c|c|c|c|c|c|c|}
\hline \multirow[b]{2}{*}{$\begin{array}{c}\text { Trial and } \\
\text { Year }\end{array}$} & \multicolumn{2}{|c|}{ SLB Incidence } & \multicolumn{2}{|c|}{$\begin{array}{c}\text { SLB Severity } \\
\text { (Leaf Dieback) }\end{array}$} & \multicolumn{2}{|c|}{ NDVI } & \multicolumn{2}{|c|}{ GNDV1 } & \multicolumn{2}{|c|}{ PSRI } \\
\hline & July & August & July & August & July & August & July & August & July & Aug \\
\hline \multicolumn{11}{|c|}{ Cultivar, 2015} \\
\hline Inc. Aug & $0.61^{1}$ & & & -0.14 & & & & & & \\
\hline NDVI & 0.17 & 0.11 & -2 & 0.14 & & & & & & \\
\hline GNDVI & -0.17 & 0.21 & - & -0.09 & 0.16 & 0.02 & & & & \\
\hline PSRI & -0.09 & -0.19 & - & -0.03 & -0.07 & -0.16 & 0.50 & 0.18 & & \\
\hline $\mathrm{CI}$ & -0.05 & 0.18 & - & -0.08 & 0.19 & -0.02 & 0.89 & 0.98 & 0.20 & 0.16 \\
\hline \multicolumn{11}{|c|}{ Fungicide, 2015} \\
\hline Inc. Aug & 0.93 & & & 0.46 & & & & & & \\
\hline NDVI & 0.02 & -0.36 & 0.05 & -0.31 & & & & & & \\
\hline GNDVI & 0.12 & -0.13 & 0.19 & -0.07 & -0.38 & 0.28 & & & & \\
\hline PSRI & 0.22 & -0.09 & 0.28 & 0.14 & 0.52 & 0.55 & -0.26 & 0.30 & & \\
\hline $\mathrm{CI}$ & 0.21 & 0.51 & 0.03 & 0.17 & 0.65 & -0.35 & -0.54 & 0.02 & 0.35 & 0.30 \\
\hline \multicolumn{11}{|c|}{ Fungicide, 2016} \\
\hline Inc. Aug & 0.99 & & & 0.47 & & & & & & \\
\hline NDVI & 0.10 & 0.06 & - & 0.01 & & & & & & \\
\hline GNDVI & 0.13 & 0.18 & - & 0.24 & 0.43 & 0.49 & & & & \\
\hline PSRI & -0.33 & -0.01 & - & -0.08 & 0.15 & -0.16 & 0.44 & -0.20 & & \\
\hline $\mathrm{CI}$ & -0.09 & 0.05 & - & 0.08 & -0.08 & -0.73 & -0.10 & -0.37 & -0.11 & 0.40 \\
\hline
\end{tabular}

${ }^{1}$ Correlation coefficients in bold are significant at $p>0.05$, Pearson correlation for SLB incidence and DSI, Spearman rank correlation for vegetative indices; ${ }^{2}$ There was no leaf dieback in the July assessment of the cultivar trial and the 2016 fungicide trial.

\section{Discussion}

In the current study, the incidence and severity of Stemphylium leaf blight was higher in 2015 relative to 2016, and blight incidence and severity differed among treatments in both years. However, these differences were not captured by the vegetative indices calculated from the aerial photographs. Stemphylium leaf blight continues to be the most important disease of onion in north-eastern North America [11], and visual assessments remain the best tool for detection and quantification of Stemphylium leaf blight.

Onion crops with higher leaf dieback caused by Stemphylium leaf blight were expected to have lower NDVI, GNDVI, and CI values (associated with leaf area index and chlorophyll content) and higher PSRI values (associated with senescence) compared to onion crops with lower incidence. There were differences in the vegetative indices among the treatments in several of the trials, but there was no relationship between the indices and visual assessments of Stemphylium leaf blight incidence or severity, which was assessed as leaf dieback. The one exception was CI and SLB incidence in the 2015 fungicide trial. PSRI values were expected to be higher for older vegetation than for younger crops [36] and this trend was observed in the current study.

There were, however, differences in the vegetative indices among the treatments. This variation was similar to that reported from Huanglongbing-infected citrus trees [5,37]. However, in contrast to those studies, the indices showed no clear relationship with levels of Stemphylium leaf blight. The differences might have been associated with other physiological conditions, such as foliage color, maturation date [29], reflectance from foliage that had received fungicide spray, or even how recently the fungicide had been applied. 
The onions in the 2015 cultivar trial did not receive fungicide applications but differed in maturity. However, the maturity of the onion cultivars was not related to SLB severity [12].

Plant stress often leads to a reduction in chlorophyll content, resulting in an increase in reflectance in the visible portion of the spectrum and a reduction in reflectance in the NIR spectrum [38-40]. However, changes in chlorophyll content are not related exclusively to disease [41]. The current study demonstrated the difficulty of early detection of Stemphylium leaf blight on onion. Onion leaf blades are upright and do not form the thick, uniform canopy that might produce more consistent readings. It was expected that the dark background of moist muck soil would provide contrast and improve the images. In fact, images taken early in the season could not be assessed because the leaves could not be distinguished from the soil background, even with images taken at only $15 \mathrm{~m}$ height. In this instance, the dark, uniform color of the muck soil was a disadvantage for image analysis, rather than the perfect background for these assessments that the authors anticipated.

Previous studies have shown that vegetative indices can also be influenced by crop senescence [29,35]. Severe Stemphylium leaf blight on onion causes extensive necrosis [15], which registers as senescence in these indices. Plant senescence reflectance index was the index most sensitive to plant canopy senescence [36]. Although there was no consistent relationship between PSRI and Stemphylium leaf blight incidence or severity, PSRI values in August were higher than in July. This observation was in agreement with previous studies in corn [29] and sunflower [36]. Differences in PSRI in the current study were likely associated with a difference in senescence among the cultivars resulting from differences in days to maturity. However, it is important to note that there was no significant association between PSRI and plant maturity, as characterized by the days to harvest information provided by the seed companies.

One important failure in this study resulted from taking the advice of experts. The commercial company that provided and flew the drone that took the aerial pictures recommended that the reflectance information be stored in JPEG format because the images are small and easy to work with. That recommendation was suitable for many of their clients but was a problem for our study in 2015 because JPEGs compression is lossy (irreversible) and results in loss of data. In 2016, the images were saved in TIFF format, which was larger but retained more data compared to JPEG. However, note that TIFF files have both lossy and lossless (reversible) compression formats [42], so care is required for any compression activity. We also lost images when the drone was not positioned directly above the ROI, which reduced the reliability of the analysis.

In many ways, this study represents a cautionary story for plant pathologists interested in using UAV technology for disease detection and quantification. For best results, flights need to be carefully monitored to ensure that suitable checks for light intensity, reflectance and cloud cover are obtained. File transfer and storage require special care, and file compression should only be undertaken with caution. Finally, simple cameras may not be suitable for disease detection and quantification. Images from hyperspectral cameras capture images that can contain as many as 200 or more contiguous spectral bands [43], which provides users with a wide range of potential indices that have the potential to be specific to specific host-pathogen interactions [27]. Using hyperspectral cameras also made it possible to separate background pixels from leaf pixels, in a study on paddy rice [44]. This would have been useful for the current study. It might be possible to develop a specific vegetative index for Stemphylium leaf blight severity using multispectral reflectance.

\section{Conclusions}

Visual assessments of incidence and severity of Stemphylium leaf blight of onion were compared to images taken with a near infrared camera carried by a low-flying drone. Disease was assessed in a cultivar trial and two trials with different timings of fungicide sprays. The digital images were processed to provide four indices related to reflectance from the leaves. Differences among treatments were found using the visual assessment and the indices. However, NDVI and other standard indices were not related to disease 
incidence or severity. To date, visual assessments remain the only useful disease assessment method for Stemphylium leaf blight on onion.

Author Contributions: Conceptualization, M.R.M. and B.D.G.; methodology, M.R.M., C.S.T.; software, C.S.T.; validation, C.S.T. and M.R.M.; formal analysis, C.S.T. and M.R.M.; investigation, C.S.T.; resources, M.R.M.; data curation, M.R.M.; writing-original draft preparation, C.S.T.; writingreview and editing, B.D.G. and M.R.M.; supervision, M.R.M. and B.D.G.; project administration, M.R.M.; funding acquisition, M.R.M. All authors have read and agreed to the published version of the manuscript.

Funding: This research was funded in part through Growing Forward 2, a federal-provincialterritorial initiative grant number GF2-0139 in cooperations with and the Bradford Cooperative Storage and the Fresh Vegetable Growers of Ontario. The Agricultural Adaptation Council assists in the delivery of Growing Forward 2 in Ontario. The research was also supported by the Ontario Ministry of Agriculture, Food and Rural Affairs/University of Guelph Partnership.

Institutional Review Board Statement: Not applicable.

Informed Consent Statement: Not applicable.

Data Availability Statement: Data supporting the results is archived in the appendix of the M.Sc. thesis of author C. Selasi Tayviah and is available at https:/ / atrium.lib.uoguelph.ca/xmlui/bitstream/ handle/10214/10430/Tayviah_CyrilSelasi_201704_MSc.pdf?sequence=1 (accessed on 22 November 2021).

Acknowledgments: We thank K. Vander Kooi, L. Riches, S. Janse, M. Mitrovic, D. Van Dyk and all the summer staff at the Muck Crops Research Station for help and advice with the field trials.

Conflicts of Interest: The authors declare no conflict of interest.

\section{References}

1. Singh, K.D.; Duddu, H.S.; Vail, S.; Parkin, I.; Shirtliffe, S.J. UAV-Based Hyperspectral Imaging Technique to Estimate Canola (Brassica napus L.) Seedpods Maturity. Can. J. Remote Sens. 2021, 47, 33-47. [CrossRef]

2. Sankaran, S.; Mishra, A.; Ehsani, R.; Davis, C. A review of advanced techniques for detecting plant diseases. Comput. Electron. Agric. 2010, 72, 1-13. [CrossRef]

3. Martinelli, F.; Scalenghe, R.; Davino, S.; Panno, S.; Scuderi, G.; Ruisi, P.; Villa, P.; Stroppiana, D.; Boschetti, M. Advanced methods of plant disease detection. Agron. Sustain. Dev. 2014, 35, 1-25. [CrossRef]

4. Shafri, H.Z.M.; Hamdan, N. Hyperspectral imagery for mapping disease infection in oil palm plantation using vegetation indices and red-edge techniques. Am. J. Appl. Sci. 2009, 6, 1031-1035.

5. Garcia-Ruiz, F.; Sankaran, S.; Maja, J.M.; Lee, W.S.; Rasmussen, J.; Ehsani, R. Comparison of two aerial imaging platforms for identification of Huanglongbing-infected citrus trees. Comput. Electron. Agric. 2013, 91, 106-115. [CrossRef]

6. Gold, K.M. Characterization of early Phytophthora infestans infection in potato with aerial, field-based hyperspectral imaging. Phytopathology 2019, 109 (Suppl. S2-2), 197.

7. McKinzie, L.; Li, R.; Bond, J.P.; Fakhoury, A.M. Assessment of plant disease using an unmanned aerial system with high resolution colour and multi-spectral imagery. Phytopathology 2019, 109 (Suppl. S2), 189.

8. Wei, X.; Langston, D.B., Jr.; Mehl, H.L. Spectral and thermal signatures of early infection of peanut with Sclerotium rolfsii. Phytopathology 2019, 109 (Suppl. S2-1), 189.

9. Zarco-Tejada, P.J. Radiative transfer retrieval of physiological plant traits for pre-visual detection of biotic stresses via air-borne hyperspectral imaging. Phytopathology 2019, 109 (Suppl. S2-2), 1.

10. Bohnerkamp, D. Hyperspectral sensors for the detection, quantification and identification of plant diseases-Demands, confounders and strengths for field detection. Phytpathology 2019, 109 (Suppl. S2-2), 197.

11. Hay, F.; Stricker, S.; Gossen, B.D.; McDonald, M.R.; Heck, D.; Hoepting, C.; Sharma, S.; Pethybridge, S. Stemphylium leaf blight of onion: A re-emerging threat to onion production in eastern North America. Plant Dis. 2021; in press.

12. Foster, J.M.; Tayviah, C.S.; Stricker, S.; Gossen, B.D.; McDonald, M.R. Pathogenicity of Stemphylium vesicarium on asparagus, onion and non-host crops in Canada. Can. J. Plant Pathol. 2019, 41, 228-241. [CrossRef]

13. Stricker, S.M.; Gossen, B.D.; McDonald, M.R. Risk assessment of secondary metabolites produced by fungi in the genus Stemphylium. Can. J. Microbiol. 2021, 67, 445-450. [CrossRef]

14. Shishkoff, N.; Lorbeer, J.W. Etiology of Stemphylium leaf blight of onion. Phytopathology 1989, 79, 301-304. [CrossRef]

15. Rao, R.N.N.; Pavgi, M. Stemphylium leaf blight in onion. Mycopathologia 1975, 56, 1-6.

16. Basallote-Ureba, M.J.; Prados-Ligero, A.M.; Melero-Vara, J.M. Aetiology of leaf spot of garlic and onion caused by Stemphylium vesicarium in Spain. Plant Pathol. 1999, 48, 139-145. [CrossRef] 
17. Pathak, S.S.; Black, S.J.; Cherng, T.C.; Ko, S.S. Breeding onions for stemphylium leaf blight resistance. Acta Hortic. 2001, 555, 77-81. [CrossRef]

18. Mishra, R.K.; Verma, A.; Singh, S.; Gupta, R.P. Screening of garlic lines against purple blotch and stemphylium blight. Pest Manag. Hortic. Ecsyst. 2009, 15, 138-140.

19. Gupta, R.P.; Srivastava, P.; Sharma, R. Plant health management. In National Horticultural Research and Development Foundation Nashik Report; The Directorate: National Horticultural Research and Development Foundation: Maharashtra, India, 2010; pp. 13-15.

20. Stricker, S.M.; Tayviah, C.S.; Gossen, B.D.; McDonald, M.R. Fungicide efficacy and timing for management of Stemphylium vesicarium on onion in Canada. Can. J. Plant Pathol. 2021; in press. [CrossRef]

21. Singh, P.; Bugiani, R.; Cavanni, P.; Nakajima, H.; Kodama, M.; Otani, H.; Kohmoto, K. Purification and biological characterization of host-specific SV-toxins from Stemphylium vesicarium causing brown spot of European pear. Phytopathology 1999, 89, 947-953. [CrossRef]

22. Singh, P.; Park, P.; Bugiani, R.; Cavanni, P.; Nakajima, H.; Kodama, M.; Otani, H.; Kohmoto, K. Effects of host-selective SV-toxin from Stemphylium vesicarium, the cause of brown spot of European pear plants, on ultrastructure of leaf cells. J. Phytopathol. 2000, 148, 87-93. [CrossRef]

23. Köhl, J.; Groenenboom-de Haas, B.H.; Kastelein, P.; Rossi, V.; Waalwijk, C. Quantitative detection of pear-pathogenic Stemphylium vesicarium in orchards. Phytopathology 2009, 99, 1377-1386. [CrossRef]

24. Llorente, I.; Moragrega, C.; Ruz, L.; Montesinos, E. An update on control of brown spot of pear. Trees Struct. Funct. 2012, 26, 239-245. [CrossRef]

25. Lorenzen, B.; Jensen, A. Spectral properties of a barley canopy in relation to the spectral properties of single leaves and the soil Remote Sens. Environ. 1991, 37, 23-34. [CrossRef]

26. McGill, M.J. Combined lidar-radar remote sensing: Initial results from CRYSTAL-FACE. J. Geophys. Res. 2004, 109, 1-13. [CrossRef]

27. Bock, C.H.; Poole, G.H.; Parker, P.E.; Gottwald, T.R. Plant disease severity estimated visually, by digital photography and image analysis, and by hyperspectral imaging. Crit. Rev. Plant Sci. 2010, 29, 59-107. [CrossRef]

28. Baranoski, G.V.G.; Rokne, J.G. A practical approach for estimating the red edge position of plant leaf reflectance. Int. J. Remote Sens. 2005, 26, 503-521. [CrossRef]

29. Hatfield, J.L.; Prueger, J.H. Value of using different vegetative indices to quantify agricultural crop characteristics at different growth stages under varying management practices. Remote Sens. 2010, 2, 562-578. [CrossRef]

30. Mahlein, A.-K.; Oerke, E.-C.; Steiner, U.; Dehne, H.W. Recent advances in sensing plant diseases for precision crop protection. Eur. J. Plant Pathol. 2012, 133, 197-209. [CrossRef]

31. Bravo, C.; Moshou, D.; Oberti, R.; West, J.S.; McCartney, A.; Bodria, L.; Ramon, H. Foliar disease detection in the field using optical sensor fusion. Agric. Eng. Int. CIGR J. 2004, 6, 1-14.

32. Deering, D.W. Rangeland Reflectance Characteristics Measured by Aircraft and Spacecraft Sensors; Texas A \& M University Press: College Station, TX, USA, 1978; p. 632.

33. Govaerts, B.; Verhulst, N. The normalized Difference Vegetation Index (NDVI) GreenSeekerTM Handheld Sensor: Toward the Integrated Evaluation of Crop Management Part A: Concepts and Case Studies; International Maize and Wheat Improvement Center (CIMMYT): Mexico City, Mexico, 2010; pp. 1-16.

34. Gitelson, A.A.; Gritz, Y.; Merzlyak, M.N. Relationships between leaf chlorophyll content and spectral reflectance and algorithms for non-destructive chlorophyll assessment in higher plant leaves. J. Plant Physiol. 2003, 160, 271-282. [CrossRef]

35. Lee, Y.J.; Yang, C.M.; Chang, K.W.; Shen, Y. A simple spectral index using reflectance of $735 \mathrm{~nm}$ to assess nitrogen status of rice canopy. J. Agron. 2008, 100, 205-212. [CrossRef]

36. Peñuelas, J.; Gamon, J.A.; Fredeen, A.L.; Merino, J.; Field, C.B. Reflectance indices associated with physiological changes in nitrogen and water-limited sunflower leaves. Remote Sens. Environ. 1994, 48, 135-146. [CrossRef]

37. Li, X.; Lee, W.S.; Li, M.; Ehsani, R.; Mishra, A.R.; Yang, C.; Mangan, R.L. Spectral difference analysis and airborne imaging classification for citrus greening infected trees. Comput. Electron. Agric. 2012, 83, 32-46. [CrossRef]

38. Kumar, R.; Silva, L. Light ray tracing through a leaf cross section. Appl. Opt. 1973, 12, 2950-2954. [CrossRef]

39. Carter, G.A. Responses of leaf spectral reflectance to plant stress. Am. J. Bot. 1993, 80, 239-243. [CrossRef]

40. West, J.S.; Bravo, C.; Oberti, R.; Lemaire, D.; Moshou, D.; McCartney, H.A. The potential of optical canopy measurement for targeted control of field crop diseases. Annu. Rev. Phytopathol. 2003, 41, 593-614. [CrossRef]

41. Moshou, D.; Bravo, C.; West, J.; Wahlen, S.; McCartney, A.; Ramon, H. Automatic detection of 'yellow rust' in wheat using reflectance measurements and neural networks. Comput. Electron. Agric. 2004, 44, 173-188. [CrossRef]

42. Patel, R.; Patel, B.P. An analytical study on comparison of different image compression formats. Int. J. Innov. Res. Sci. Technol. 2014, 1, 24-31.

43. Adam, E.; Mutanga, O.; Rugege, D. Multispectral and hyperspectral remote sensing for identification and mapping of wetland vegetation: A review. Wetl. Ecol. Manag. 2010, 18, 281-296. [CrossRef]

44. Zhou, K.; Cheng, T.; Zhu, Y.; Cao, W.; Ustin, S.L.; Zheng, H.; Yao, X.; Tian, Y. Resolution on the estimation of leaf nitrogen concentration over the full season of paddy rice using near-surface imaging spectroscopy data. Front. Plant Sci. 2018, 9, 964 [CrossRef] 